\title{
38. SEISMIC STRATIGRAPHY AND STRUCTURE ADJACENT TO AN EVOLVING PLATE BOUNDARY, WESTERN CHATHAM RISE, NEW ZEALAND ${ }^{1}$
}

\author{
K. B. Lewis, New Zealand Oceanographic Institute \\ D. J. Bennett, Geophysics Division of the Department of Scientific and Industrial Research, New Zealand \\ R. H. Herzer, New Zealand Geological Survey \\ and \\ C. C. von der Borch, Flinders University ${ }^{2}$
}

\begin{abstract}
Seismic profiles obtained from the eastern side of New Zealand, in transit to and from Site 594, illustrate the evolution of the western end of the Chatham Rise and the southern extremity of the Hikurangi Trough. They show several unconformities and several major changes in tectonic and depositional regime. The unconformities represent major changes in oceanic circulation, possibly triggered by large lowerings of sea level in the late Oligocene and late Miocene. Tectonism is exemplified by a Late Cretaceous phase of block faulting, heralding the rift from Gondwanaland, and by Plio-Pleistocene normal faulting on the northern flank of the rise antithetic to the oblique-collision plate boundary in the southern Hikurangi Trough. This active normal faulting may indicate that the northwestern corner of Chatham Rise continental crust is being dragged down with the subducting slab to the north. The depositional regime has changed from Late Cretaceous infilling of fault-angle depressions, through an early Tertiary transgression and mid-Tertiary carbonate drape, to a late Miocene-Recent sequence recording repeated glacial-interglacial events. This upper stratified unit onlaps a late Miocene erosion/phosphatization unconformity toward the crest of the rise. It is locally truncated by a slope-parallel erosion surface, with downslope buildup, which may indicate either current scour and deposition or mass movement.
\end{abstract}

\section{INTRODUCTION}

\section{Background}

In transit between Cook Strait and Site 594, the Glomar Challenger obtained seismic profiles along approximately $900 \mathrm{~km}$ of ship's track. Because they are tied to borehole data and because they cross areas where tracks are sparse, the Glomar Challenger profiles provide a significant increase in our understanding of the stratigraphy of eastern New Zealand and of tectonism in continental crust adjacent to an oblique-collision plate boundary.

In this paper we integrate the Glomar Challenger profiles with published syntheses, with seismic data obtained by D.S.I.R. divisions, and with compilations of oil company data on open file at the New Zealand Geological Survey. Oil company data used in this study include profiles collected by Mobil Oil Corporation, Magellan Petroleum (New Zealand) Ltd., Australian Gulf Oil company, and B.P. Shell Todd (Chatham Rise) Ltd.

\section{Geomorphological Setting}

The Glomar Challenger profiles traverse the Mernoo Saddle, a depression between the continental shelf of eastern New Zealand and the east-west-trending Chatham Rise (Fig. 1; Fig. 3, later). The saddle's sill depth is over $500 \mathrm{~m}$ deep, contrasting with shelf depths to east

\footnotetext{
${ }^{1}$ Kennett, J. P., von der Borch, C. C., et al., Init. Repts. DSDP, 90: Washington (U.S. Govt, Printing Office).

2 Addresses: (Lewis) New Zealand Oceanographic Institute, D.S.I.R., P.O. Box 12-346, Wellington, N.Z.; (Bennett, present address) New Zealand Oil and Gas Ltd., P.O. Box 3149, Wellington, N.Z., (Herzer) New Zealand Geological Survey, D.S.I.R., P.O. Box 30-368, Lower Hutt, N.Z; (von der Borch) Flinders University, Bedford Park, S.A. 5042 , Australia.
}

and west. It separates the gently sloping head of the Bounty Trough to the south from the steeper-sided head of the Hikurangi Trough to the north. To the east is the flat-topped Mernoo Bank at the western end of the Chatham Rise. To the west is the weathered volcanic mass of Banks Peninsula and beyond lie the Canterbury Plains and the high ramparts of the Southern Alps.

\section{Physical Oceanography}

The Chatham Rise is a significant barrier to ocean circulation. Its crest corresponds with a Subtropical Convergence Zone between Subtropic Water, which has flowed around northern New Zealand as the East Cape Current, and mixed Subantarctic Water, which has flowed around southern New Zealand as the Southland Current (Fig. 1; Burling, 1961; Heath, 1972, 1976). Although subtropical species such as flying fish live in the waters off eastern North Island, icebergs large enough to ground on the shallower parts of the Chatham Rise have often been reported off eastern South Island (Brodie and Dawson, 1971) and Antarctic erratics have been dredged from the Chatham Rise (Cullen, 1962).

The Mernoo Saddle is the only significant gap in the barrier. As the main currents turn east along the rise, a branch of the cool Southland Current flows through the gap to mix in complex eddies with water that has flowed from the north and through Cook Strait. In addition, low-salinity water rises from a depth of about $700 \mathrm{~m}$ to maintain a slow $(0.08 \mathrm{~m} / \mathrm{s})$ northward net drift across the deeper parts of the saddle (Heath, 1976). Maximum tidal speeds through the gap reach $0.44 \mathrm{~m} / \mathrm{s}$ (Heath, 1976), which is more than enough to move sediment (Carter and Herzer, 1979). 


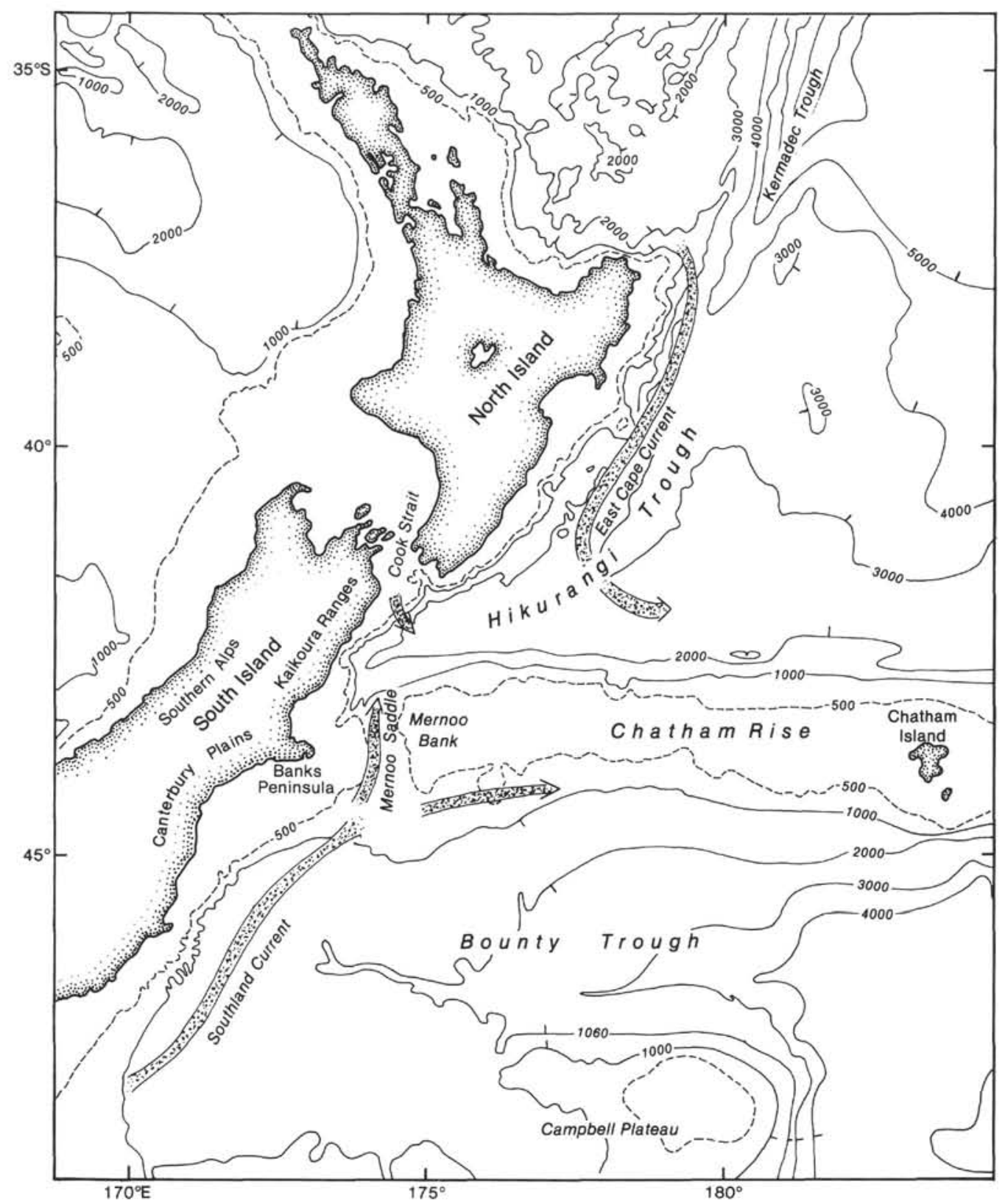

Figure 1. Main topographic features and oceanic circulation off eastern New Zealand. Contours at $1000 \mathrm{~m}$ intervals plus broken contour at $500 \mathrm{~m}$ depth. (Bathymetry from Carter, 1980, currents from Heath, 1976.)

Along the east coast of South Island, storms are mainly from the south, again producing a net overall northward drift of water and entrained sediment.

During periods of lowered sea level, when the Canterbury Shelf and Mernoo Bank were exposed, flow through the Mernoo Saddle between contrasting water masses could have been even more constricted and more intense than at present. Even if the Subtropical Convergence shifted to the north of New Zealand, the Chatham Rise would still have been a barrier between water masses that had flowed around the northern and southern ends of New Zealand.

\section{Tectonic Setting}

The apex of the Hikurangi Trough, just north of the Mernoo Saddle, represents the southern limit of the Ton-
ga-Kermadec-Hikurangi Subduction System (Fig. 2). This system is characterized by subduction of the Pacific Plate beneath the Indo-Australian Plate. Along the sedimentflooded Hikurangi Trough, the Pacific Plate dives beneath the continental crust of northeastern New Zealand, which is being plated with an imbricate-thrust, accretionary prism (Lewis, 1980). The Pacific Plate is probably oceanic crust southward to the latitude of southernmost North Island. The apex of the trough appears to be underlain by downwarped epicontinental crust of the Chatham Rise, which is underthrusting the rapidly rising Kaikoura Ranges.

Along the Hikurangi Margin there is wide zone of deformation where the edge of the Indo-Australian Plate interacts with the obliquely underthrusting Pacific Plate. The outer feather edge is characterized by the accretion- 


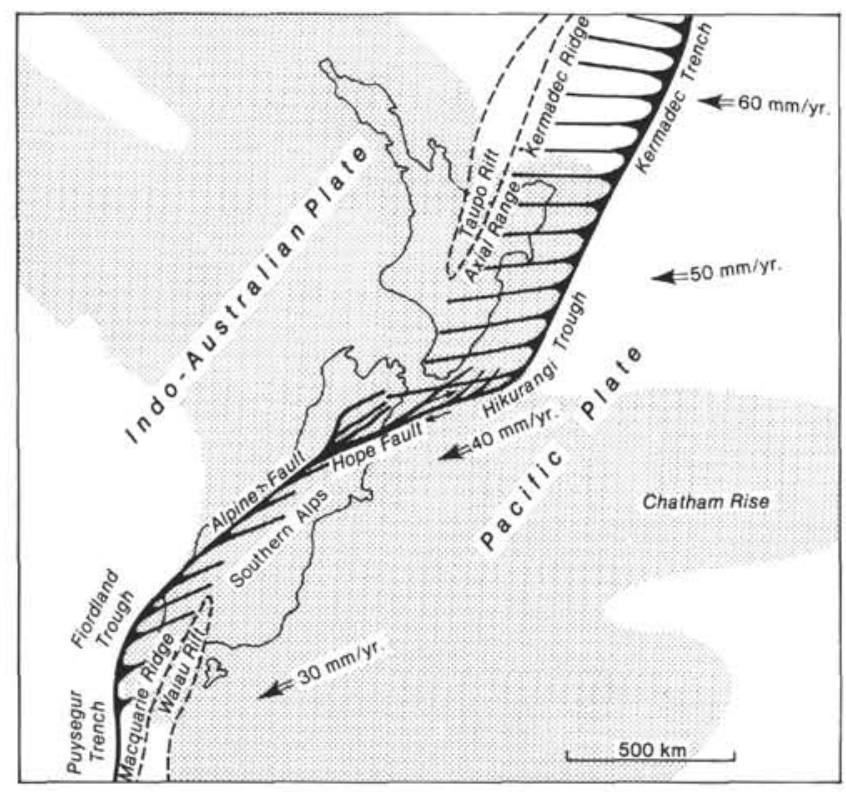

Figure 2. Major elements of the Indo-Australian/Pacific plate boundary in the New Zealand Region. Stippling represents continental crust. Arrows show relative motion of Pacific Plate with respect to the Indo-Australian Plate. Lines represent direction of motion of underthrusting plate (adapted from Walcott, 1978, and Lewis, 1980).

ary prism, which merges landward into a subparallel series of dextral transcurrent faults that link southward into the Alpine Fault (Lewis, 1980). In northeastern South Island the dextral faults form the Marlborough Shear Zone, which is thought to be propagating southward (Ryan and Scholz, 1978) as mirror-image subduction zones north and south of New Zealand move further apart (McKenzie and Morgan, 1969). The underthrust Pacific Plate can be detected beneath the more northerly faults of the Marlborough Shear Zone (Arabasz and Robinson, 1969; Adams and Ware, 1977) but not beneath the southern limit of the zone at the Hope Fault nor at an evolving lineament to the south (Carter and Carter, 1982; Herzer and Bradshaw, in press).

The Alpine Fault is an intracontinental trench-trench transform. In western South Island there is a component of compression across the fault, with the Indo-Australian Plate being thrust under the Pacific Plate (Allis, 1981) and pushing up the edge of the Pacific Plate to form the Southern Alps.

Thus, the western end of the Chatham Rise is on the Pacific Plate close to the northern end of the obliquecollision, trench-trench plate boundary through continental New Zealand. It is to be expected that it will exhibit some structural and stratigraphic evidence of its proximity to this boundary.

\section{Tectonic History}

Up to the end of Early Cretaceous Rangitata Orogeny, the history of New Zealand was that of a Pacific margin of Gondwanaland (Spörli, 1980). In the Late Cretaceous, widespread block faulting and graben formation heralded the break-up of this margin (Austin, 1973a, b). The Rangitata Foldbelt, part of which now forms the Chatham Rise, split away from its foreland along a rifted basin, part of which now forms the Bounty Trough (Davey, 1977). The Bounty Trough rift failed and the successful Tasman Sea rift opened up in the foreland to the west. As the Tasman Sea opened in the latest Cretaceous and Paleocene, the foldbelt, the rifted basin, and a segment of foreland rotated together out into the Pacific Ocean (Cullen, 1970; Spörli, 1980) to form the basic elements of the New Zealand Continental Plateau. The southeastern segment of foldbelt has formed the Chatham Rise, the southeastern part of the rifted basin has formed the Bounty Trough, and the Campbell Plateau to the south survives as a remnant of Gondwana foreland.

The Palaeogene was a period of quiescence-of slow subsidence of the New Zealand Plateau as it drifted away from the spreading plate boundary. There was widespread marine transgression and peneplanation of the few remaining low-lying landmasses (Fleming, 1962; Carter and Norris, 1976; Suggate, 1978). With cessation of spreading in the Tasman and opening of the seaway between Australia and Antarctica, the initiation of the Circum-Antarctic Current (Kennett et al., 1975) bought widespread marine erosion, not only in the Southern Ocean but perhaps also on the margins around New Zealand (Carter and Norris, 1976).

At some stage in the Oligocene the present dextrally slipping, trench-trench transform plate boundary bisected the New Zealand continental plateau. In the late Oligocene and early Miocene, there was a component of extension along the boundary that changed to gradually increasing compression after late Miocene times (Carter and Norris, 1976), as the Indo-Pacific pole of rotation moved southward (Walcott, 1978). This increasing compression is expressed as the Plio-Pleistocene Kaikoura Orogeny, which has elevated the mountain chains of New Zealand. The rising mountains have changed patterns of sedimentation on adjacent margins from dominantly calcareous to increasingly coarse clastic debris (Prebble, 1980).

\section{WESTERN CHATHAM RISE}

\section{Existing Knowledge}

The Chatham Rise is a broad, east-west geanticline with Tertiary formations draped over a core of upper Paleozoic or lower Mesozoic greywacke and chlorite schist of the old Rangitata Foldbelt (Houtz et al., 1967; Cullen, 1980). Samples of schist, of Eocene and lower Miocene limestone, and of phosphatized nodules of Oligocene, lower Miocene, and lower middle Miocene limestone have been dredged from near the ridge crest (Cullen, 1965, 1980; Pasho, 1976). The nature and distribution of limestone on the central rise, on the Chatham Islands, and in central Canterbury suggests that the Chatham Rise was a marginal plateau, remote from large-scale detrital input, for most of the early Tertiary (Suggate, 1978). At some time in middle to late Miocene time there was a phase of erosion with phosphatization of exposed limestone and eroded clasts (Cullen, 1967).

Since the end of the Miocene Epoch, sediments have blanketed the flanks of the rise while the crest has remained largely sediment-free. The northwest corner of 
the Chatham Rise has been downwarped and buried by up to $4 \mathrm{~km}$ of flat-lying Plio-Pleistocene turbidites (Katz, 1974) derived from rapidly rising mountains to the south. This northern margin is heavily faulted but the nature and age of faulting is inconclusive from existing data (Ewing et al., 1969; Davey, 1977).

The westward continuation of the Chatham Rise now lies buried beneath the gravel fans of the Canterbury Plains and the prograding clastic wedge of the Canterbury continental shelf (Herzer, 1981). These deposits have built around the upper Miocene shield volcano (Stipp and McDougall, 1968) of Banks Peninsula. Groups of young, probably upper Cenozoic volcanic knolls occur along the southern flank of the western Chatham Rise, an area heavily scoured by channels and scarred by slope failure (Herzer, 1975).

\section{Importance of Glomar Challenger Data}

Site 594 (Fig. 3) is the first drill site in the Chatham Rise-Bounty Trough area and it therefore presents an unrivalled opportunity for the stratigraphic interpretation of existing seismic data. Two exploration wells have been drilled on the continental shelf to the west of Site 594 (Anon., 1971, 1975). Both are sited in the thick Neogene clastic wedge and their Neogene stratigraphy is difficult to trace, in seismic sections, to the thin distal facies of the rise and trough. However, the Paleogene stratigraphy can be traced with more success, providing the basis for our interpretation of the deeper seismic stratigraphy. The position of Site 594 was selected on the basis of Eltanin profile E43 (Fig. 3, 4) (Davey, 1977). Profiles obtained by Glomar Challenger in transit to and from Site 594 (Fig. 3; Fig. 5, back pocket) and reported on here show more stratigraphic and structural detail in the upper $1 \mathrm{~km}$ or so of sediment than most of the deeppenetration commercial data. The course of Glomar Challenger on return from Site 594 was designed to provide increased coverage of the northern flank of the rise, where earlier data indicated structural and erosional complexities in the near-surface layers.

\section{METHODS}

Data were collected using a watergun with an $80 \mathrm{cu}$. in. chamber, firing at $10 \mathrm{~s}$ intervals. Firing pressure was $1000 \mathrm{psi}$, and a $40-160 \mathrm{~Hz}$ bandpass filter was employed.

\section{SEISMIC STRATIGRAPHY RESULTS}

\section{Seismic Stratigraphy near Site 594}

An appraisal of the Eltanin site selection profile $E 43$ (Fig. 4) and of the southward transit profile (Fig. 5,B$B^{\prime}$ ) suggest that there are three regional unconformities in the top $1 \mathrm{~s}$ or so (two-way traveltime) of seismic section. The unconformities are recognized by local angular discordances in reflectors, such as truncation and baselap, which imply hiatuses in deposition (Vail et al., 1977). In the Bounty Trough they pass into strong reflectors that separate seismic sequences with markedly different characteristics. The unconformities recognized here appear to correlate with the reflectors labeled from the top,
Y, X, and A by Davey (1977), A being widely recognized on the eastern Chatham Rise (Austin, 1973a, b). They separate three seismic sequences and an acoustic basement that has markedly different characteristics in different places.

Site 594 lies immediately south and off-structure from a basement high with anticlinal drape of overlying sediments (Fig. 6). Because of the proximity of the high, acoustic reflectors are confused immediately below the drill site. However, the major reflectors and sequences can be extrapolated to the drill site.

The top seismic sequence consists of closely spaced, high-amplitude, near-parallel reflectors with some minor internal convergences or unconformities. It correlates with the "stratified layer" of Davey (1977) and is labeled here acoustic Unit A. At the drill site its acoustic thickness is $320 \mathrm{~ms}$ (Fig. 6). The interval velocity in this near-surface layer was measured in core sections and found to be $1500-1600 \mathrm{~m} / \mathrm{s}$. Thus, its thickness is about $250 \mathrm{~m}$. Unit A onlaps older sequences toward the north and thins gradually toward the south with development of incised channels in the Bounty Trough (Fig. 4).

Between unconformities $\mathrm{Y}$ and $\mathrm{X}$ is the Transparent Layer of Davey (1977), characterized by intermittent, widely spaced, low-amplitude reflectors, which are more coherent in the lower half of the sequence. It is labeled here acoustic Unit B. Estimates based on the profile $E 43$ and an extrapolation of Reflector X on Glomar Challenger's transit profiles (Fig. 6) suggest that Unit B is represented by about $430 \mathrm{~ms}$ of seismic penetration at Site 594. Its interval velocity measured in core sections averaged $1600 \mathrm{~m} / \mathrm{s}$ but refraction data indicate velocities in the range of $1900-2200 \mathrm{~m} / \mathrm{s}$ (B. W. Davy, Geophysics Division, D.S.I.R., pers. comm., 1984). If an interval velocity of $2000 \mathrm{~m} / \mathrm{s}$ is used then Unit B must be about $430 \mathrm{~m}$ thick, and its base must be about $680 \mathrm{~m}$ below the seafloor. Unit B thins rapidly toward the north with apparent onlap onto Reflector X and erosional truncation at Reflector Y, although the diffuse internal reflectors make identification of lapout difficult. It thickens gradually toward the axis of the Bounty Trough (Fig. 4).

Beneath Reflector X is a sequence that for the purposes of the present study can be labeled acoustic Unit C. At most places there is a strong reflector, Reflector $\mathrm{A}$, at its base. At some places the basal reflector has the appearance of volcanic or intrusive knolls, at others of block-faulted Mesozoic basement, and at others of a strong intrasedimentary reflector. Unit C contains only a few low-amplitude reflectors. At the drill site the thickness of Unit C, which was not penetrated by drilling, appears to be represented by a seismic interval of about $190 \mathrm{~ms}$. If a seismic velocity of $3000 \mathrm{~m} / \mathrm{s}$ is used (B. W. Davy, Geophysics Division, D.S.I.R., pers. comm.) then its thickness is about $280 \mathrm{~m}$.

\section{Correlation with Logs of Site $\mathbf{5 9 4}$}

Site 594 was drilled to a total depth of $639.5 \mathrm{~m}$ below the seafloor, penetrating acoustic Unit A and most of acoustic Unit B. The boundaries of the seismic sequences described here do not correspond with the bound- 


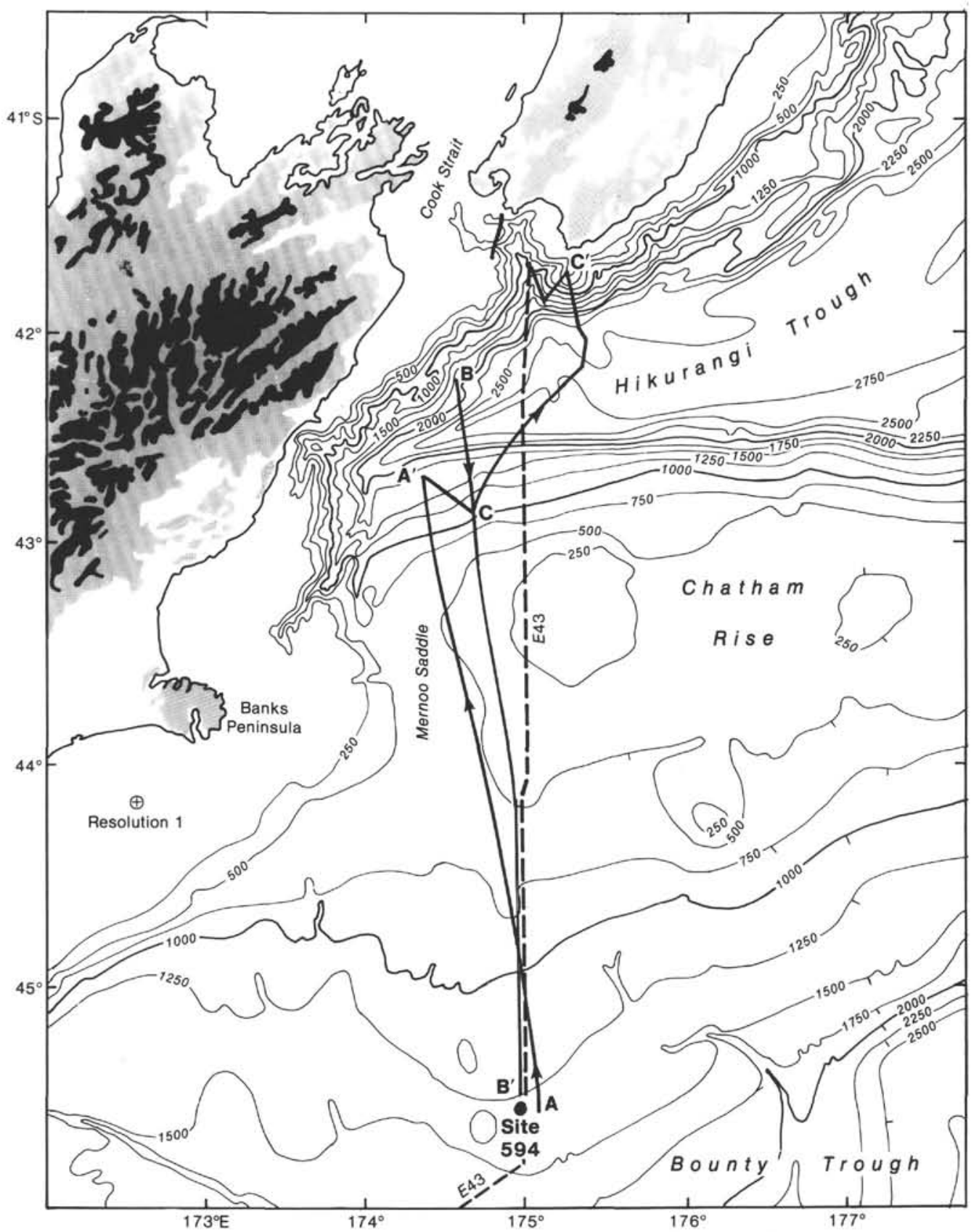

Figure 3. Detailed topography and bathymetry adjacent to the western end of the Chatham Rise with position of Glomar Challenger transit profiles A-A', B-B', and C-C' (see Fig. 5), to and from Site 594, and of site selection profile Eltanin E43. On land, solid at $>1000 \mathrm{~m}$, stippled at $250-1000 \mathrm{~m}$. Isobaths at $250 \mathrm{~m}$ intervals from van der Linden (1968) and Krause and Cullen (1970).

aries of designated lithostratigraphic units at the drill site but do correspond with changes in sedimentary regime (Fig. 6).

The stratified acoustic Unit A is represented in the drill samples by stratified upper Miocene to Recent pelagic and hemipelagic oozes (Nelson, Jarrett, et al.; Nelson, Hendy, Cuthbertson et al.; both this volume). The upper half of the acoustic unit correlates with lithostratigraphic Unit I, at $0-160 \mathrm{~m}$ sub-bottom depth, consisting of alternating pelagic nannofossil ooze and hemipelagic nannofossil-bearing clayey silt of early Pliocene to Recent age. Individual pelagic-hemipelagic cycles range from 0.5 to $10 \mathrm{~m}$ thick and contacts are gradational. They are interpreted as interglacial/glacial cycles, the hemipelagic silty layers representing glacial periods of increased sediment supply from the rising mountain ranges of New Zealand and increased dissolution of pelagic carbonate (Griggs et al., 1983). At least 25 major influxes of silt have occurred during the last $5 \mathrm{Ma}$.

The lower half of acoustic Unit A, at $160-250 \mathrm{~m}$ subbottom, may underly a local minor unconformity. It corresponds with the top of lithostratigraphic Unit IIA and consists of uppermost Miocene to basal Pliocene, alternating pure and impure pelagic nannofossil oozes. 


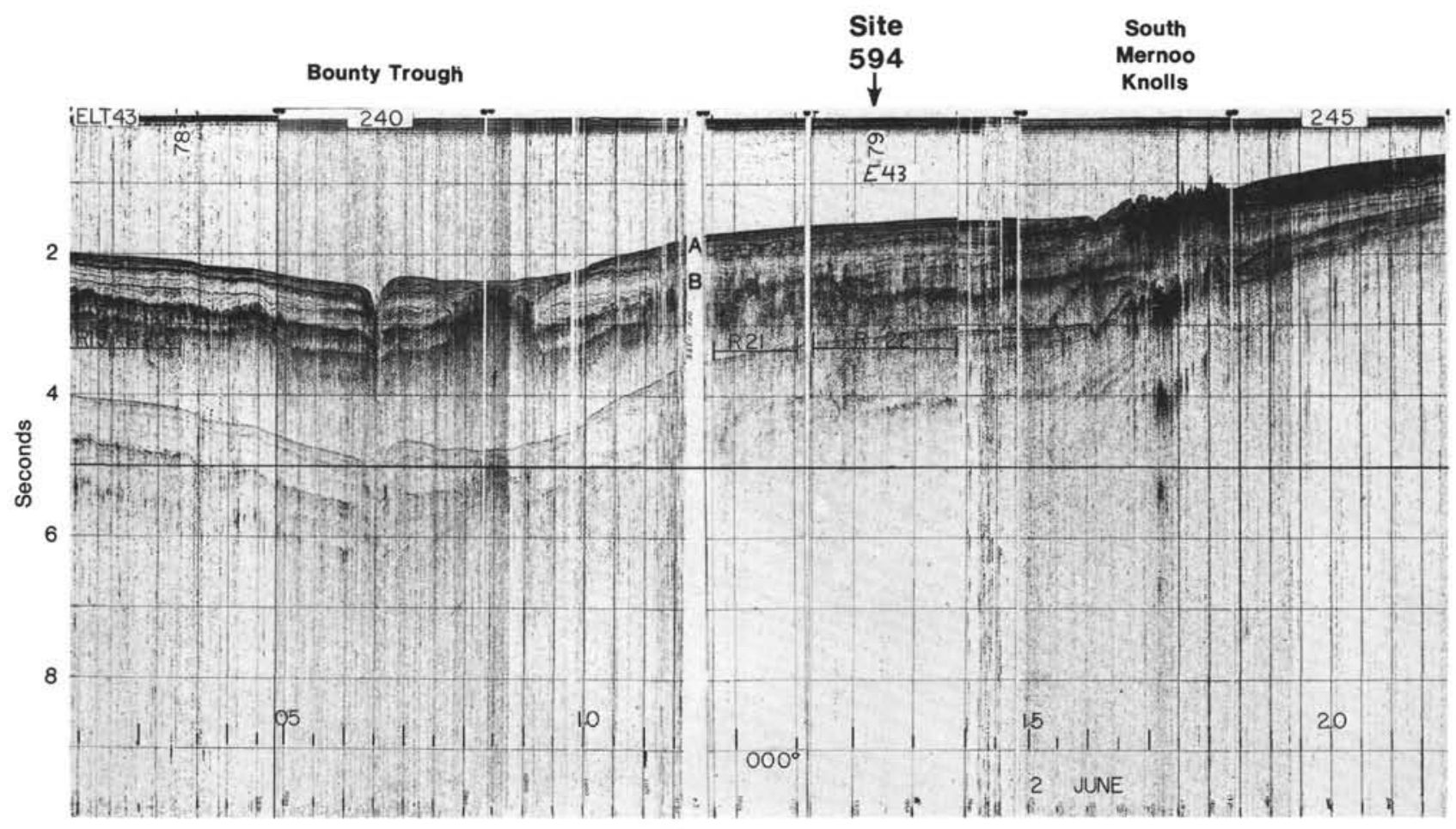

Figure 4. Site selection profile from Eltanin E43 showing surface stratified layer (acoustic Unit A) and underlying transparent layer (acoustic Unit B) thinning toward the crest of the Chatham Rise. Lines at $1 \mathrm{~s}$ intervals (two-way traveltime) equivalent to $750 \mathrm{~m}$ in seawater.

The thin impure intervals are enriched in diatoms, sponge spicules, mica, foraminifers, and/or thin lenses of silt and clay. They are again interpreted as a response to increased glacial-age carbonate dissolution (Griggs et al., 1983). Thus, the closely spaced, high-amplitude signals from acoustic Unit A appear to be a seismic response to the stratification associated with latest Miocene to Recent glacial/interglacial changes. The unconformity Y at its base has a negligible angular difference in dip at the drill site and was not detected in lithostratigraphic or biostratigraphic analysis of core samples.

The "transparent" acoustic Unit B is represented in the core by Miocene nannofossil ooze or, below $470 \mathrm{~m}$, where it is more consolidated, by Miocene nannofossil chalk. The upper part of Unit B, which has only a very few low-amplitude reflectors, corresponds with the almost featureless mid and upper Miocene nannofossil ooze of the lower part of lithostratigraphic Unit IIA. The lower part of acoustic Unit B, which has more coherent low-amplitude reflectors, corresponds with the lower Miocene to basal middle Miocene lithostratigraphic Unit IIB, which is composed of nannofossil chalk with interbeds of silt-bearing clayey nannofossil chalk. The interbeds have sharp erosional bases and are interpreted as turbidite deposits.

The base of acoustic Unit B was not sampled at Site 594, and acoustic Unit C lies well below the total depth of drilling.

\section{South Mernoo Knolls}

South of the Mernoo Saddle, there are scattered knolls with positive magnetic anomalies which are considered to be the products of Neogene volcanism (Herzer, 1975).
The two Glomar Challenger transit profiles (Fig. 5) cross one group of these knolls, and the stratigraphy devised at Site 594 can be traced northward across them only with difficulty. However, correlation is possible on the basis of broad similarities in seismic character and with the help of oil industry profiles in the area.

The uppermost Miocene to Recent acoustic Unit A onlaps unconformity $\mathrm{Y}$ at its base toward the knolls (Figs. 5, 6). It can be distinguished to the north of the knolls as a unit of similar seismic character and thickness. Within the group of knolls, channels some $200 \mathrm{~m}$ deep appear to have been scoured into the upper sedimentary layers and partly or completely infilled. The channels commonly appear to have been moatlike depressions around individual volcanic pinnacles. Immediately to the north of the group of knolls (Fig. 5A), the presence of a channel with onlap or prograded fill at the uppermost Miocene unconformity Y suggests that the volcanic pinnacles are at least partly older than late Miocene in age. Acoustic Unit B is correlated, with some uncertainty, with a much thinner, more stratified sequence in a similar stratigraphic position north of the knolls. It may be supposed that the different seismic character is the product of a different, perhaps slightly higher-energy environment near the rise crest. Convergence of reflectors toward the knolls may indicate some disturbance of the seafloor at this position during the deposition of at least the younger part of acoustic Unit B. Doming of reflectors above the basement high near the drill site could indicate either sheet drape over a pre-existing high in a low-current environment or doming by a magma diapir or velocity pull-up of thermally metamorphosed sediments. 


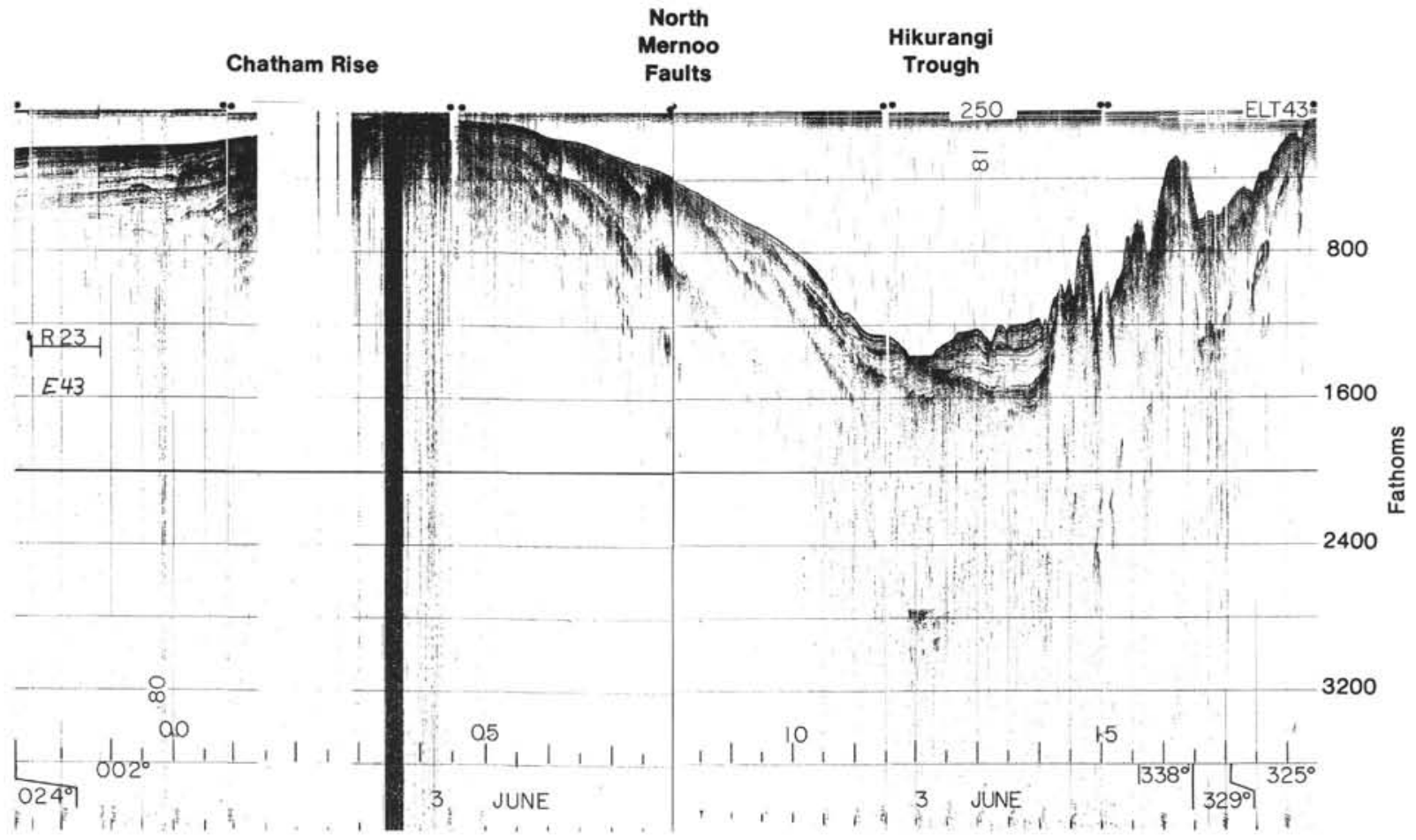

Figure 4. (Continued).

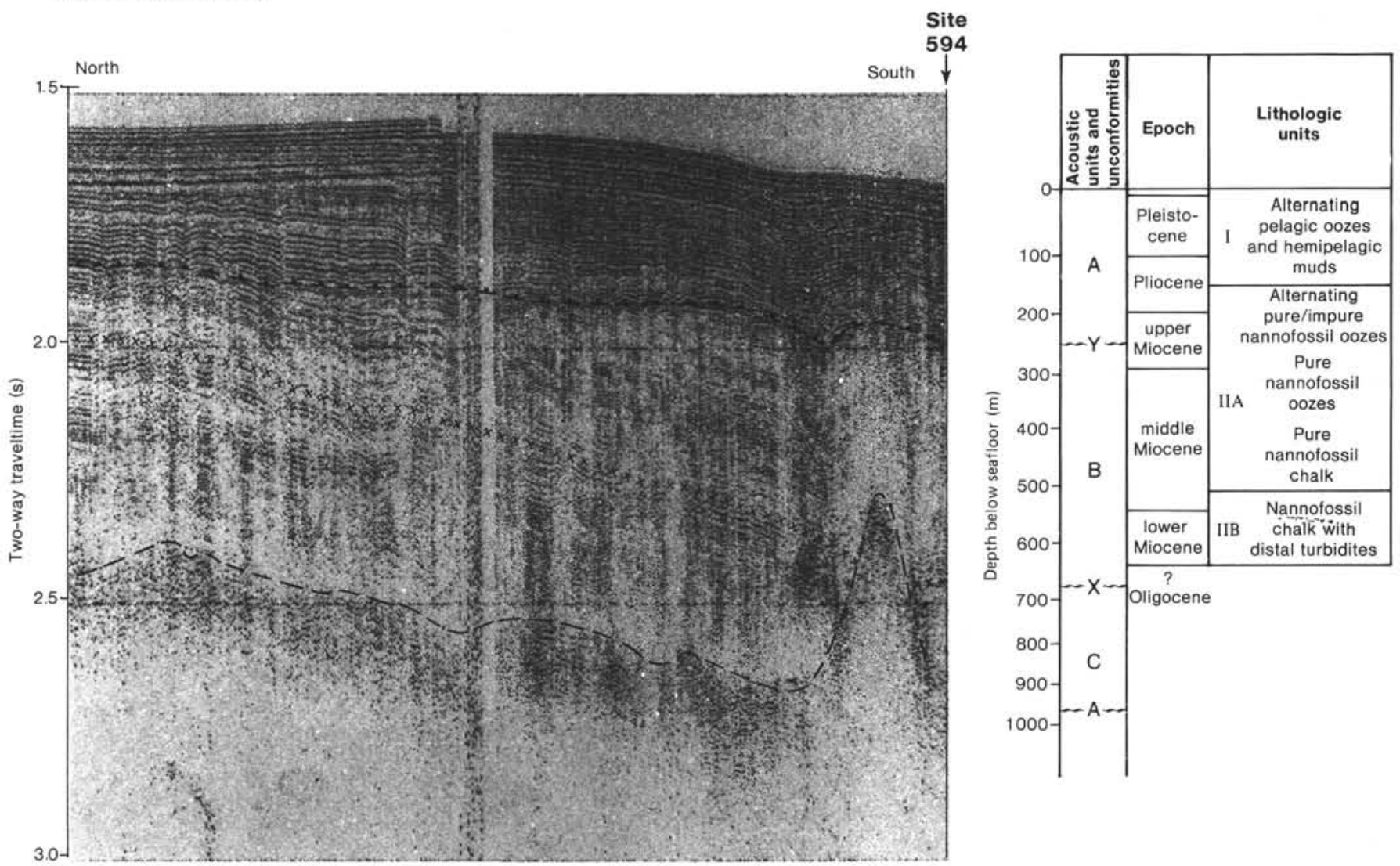

Figure 6. Correlation between seismic stratigraphy in transit profile and borehole stratigraphy at Site 594. Indicated are unconformities $\mathrm{Y}, \mathrm{X}$, and A separating acoustic Units A, B, C, and acoustic basement. 
Unconformity X, which defines the base of Unit B, can be correlated north of the knolls, although it becomes less seismically reflective toward the crest of the rise and away from the Bounty Trough.

\section{Crest of the Rise}

The profiles across the Mernoo Saddle (Fig. 5) show the planed geanticlinal structure typical of the ridge crest further east.

The only rock samples from the vicinity are supposed Permian-Jurassic greywackes dredged from Mernoo Bank (Norris, 1964; McDougall, 1982). These almost certainly correlate with acoustic basement that outcrops at the crest of the saddle. The basement is faulted to form several half-grabens or fault-angle depressions, which are fault-bounded on their northern side; that is, faults are downthrown to the south. Similar tensional faulting in basement occurs at the eastern end of the Chatham Rise, where both fault-angle depression formation and infilling are inferred to be Late Cretaceous in age (Austin et al., 1973a, b). Late Cretaceous fault-angle depressions occur on the southern slopes of the Chatham Rise and into the Bounty Trough (B. W. Davy, Geophysics Division, D.S.I.R., pers. comm.) and on land in South Island (Carter and Norris, 1976), where in each case they are correlated with rifting that preceded opening of the Tasman Sea. Thus, it is assumed that formation of fault-angle depressions and their subsequent infilling is also largely of Late Cretaceous age in the Mernoo Saddle.

The mainly lower and middle Miocene acoustic Unit B and lower Tertiary Unit C onlap and thin toward the crest of the rise but apparently cover much of it. This supports a suggestion (Kennett and Casey, 1969) that the rise has been a submarine bathymetric feature since the early Tertiary.

The uppermost Miocene to Recent acoustic Unit A onlaps the upper Miocene unconformity toward the crest of the rise. The upper Miocene period of planation probably represents the time when lower Oligocene to middle Miocene limestones were exposed at the seabed and phosphatized (Cullen, 1980). Along much of the rise the phosphatized limestones have apparently remained at or near the seabed ever since, but in the Mernoo Saddle they are buried by surficial sediments (McDougall, 1982) too thin to be detected on the present profiles.

\section{North Mernoo Slope}

The slope between Mernoo Saddle and the southwestern end of the Hikurangi Trough bears evidence of major Neogene tectonic activity and of post-depositional changes to Neogene sediments. In this it differs significantly from any other areas of the passive Chatham Rise.

The seismic sequences recognized south of the Chatham Rise are tentatively correlated here with a similar sequence north of the rise (Fig. 5). There is an onlapping upper sequence correlated with acoustic Unit A and underlying transparent units between strong reflectors correlated with acoustic Units B and C.
The seismic sequences of the whole slope are fractured by faults that are, with one or two possible exceptions, all downthrown to the south (Figs. 5, 7). The band of faulting extends approximately east-west, and tentative correlations of individual faults suggest a similar trend. The majority of the faults are of late Neogene origin, as they cut acoustic Unit A, some showing evidence of continued growth during deposition of the unit and some producing a scarp at the seabed. The majority do not show evidence of increased throw in units older than late Neogene in age. Some older units thin toward the rise crest, giving a false impression of growth fill in a fault-angle depression. However, there are faults, including several near the rise crest, that show either dislocation of older units only or increased throw in older units, indicating movement on older faults before late Neogene faulting and movement. The age of faulting before the late Neogene is uncertain because of uncertainties in the correlation of seismic sequences below Unit A. However, similar faulting elsewhere on the Chatham Rise is Late Cretaceous in age (Austin et al., 1973a, b).

Plots of earthquake epicenters show that there is significant seismic activity under the area of Neogene faulting (Arabasz and Robinson, 1976). This activity, which is clearly in the Pacific Plate, occurs on the eastern fringe of a diffuse zone of intense activity marking the plate boundary zone to the west. Thus, the seismology indicates active faulting related to the boundary zone. Fault plane solutions, which would show the faulting regime, are not available for this area.

The vertical exaggeration of the transit profiles is such that the dip direction of fault planes is difficult to ascertain, but available oil industry profiles, with low vertical exaggeration (Fig. 7), clearly show the faults to be normal, indicating a tensional regime adjacent to an oblique collision boundary. Industry and D.S.I.R. data show that this band of normal faulting, here termed the North Mernoo Fault Zone, dies out about $100 \mathrm{~km}$ east of the Glomar Challenger tracks and disappears westward beneath the clastic wedge of the Canterbury shelf.

Besides being offset by faulting, acoustic Unit A is erosionally truncated on the northern slope of the Mernoo Saddle between depths of about $700 \mathrm{~m}$ and $1700 \mathrm{~m}$, with increased erosion between $1500 \mathrm{~m}$ and $1700 \mathrm{~m}$ (Figs. 5, 8). Davey (1977), who described the erosion as a product of slumping, showed that it closely paralleled the contours. Downslope from the scour, Unit A is much thickened, with local discontinuities but still with closely spaced, high-amplitude, sub-parallel reflectors. There are only small patches of contorted bedding both at the seabed and buried within Unit A.

\section{Southern Hikurangi Trough and Accretionary Margin}

In the southern extremity of the Hikurangi Trough, the correlative of acoustic Unit A changes character to a thick sequence of near-horizontal reflectors which are deformed along the toe of the eastern margin of New Zealand (Fig. 5). The uppermost Miocene unconformity $\mathrm{Y}$, at the base of Unit A, is too deep to be detected on 


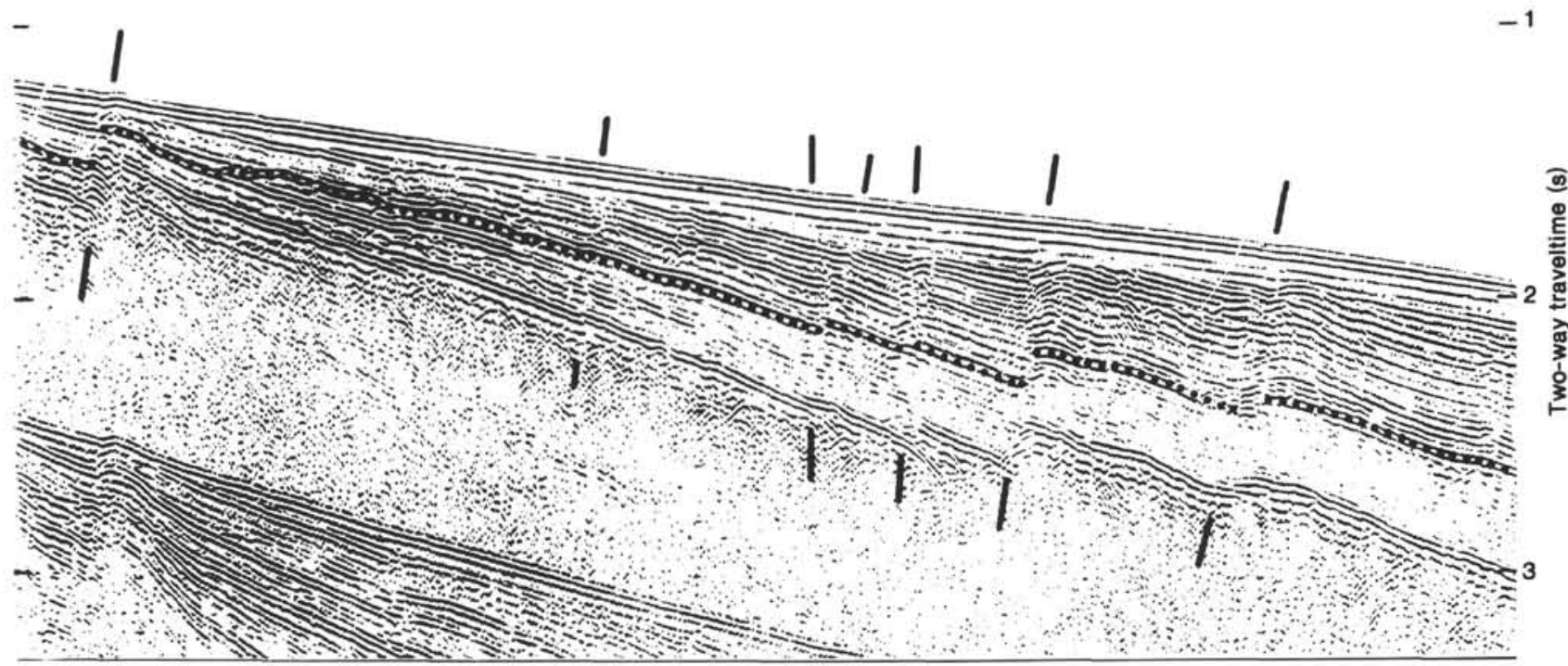

Figure 7. Seismic profile Magellan G-9 across North Mernoo Fault Zone (water depth 800-1450 m) showing dip of most normal faults toward the crest of the Chatham Rise. Unconformity Y, at base of acoustic Unit A, is stippled. Lines at $1 \mathrm{~s}$ intervals (two-way traveltime), equivalent to $750 \mathrm{~m}$ in seawater.

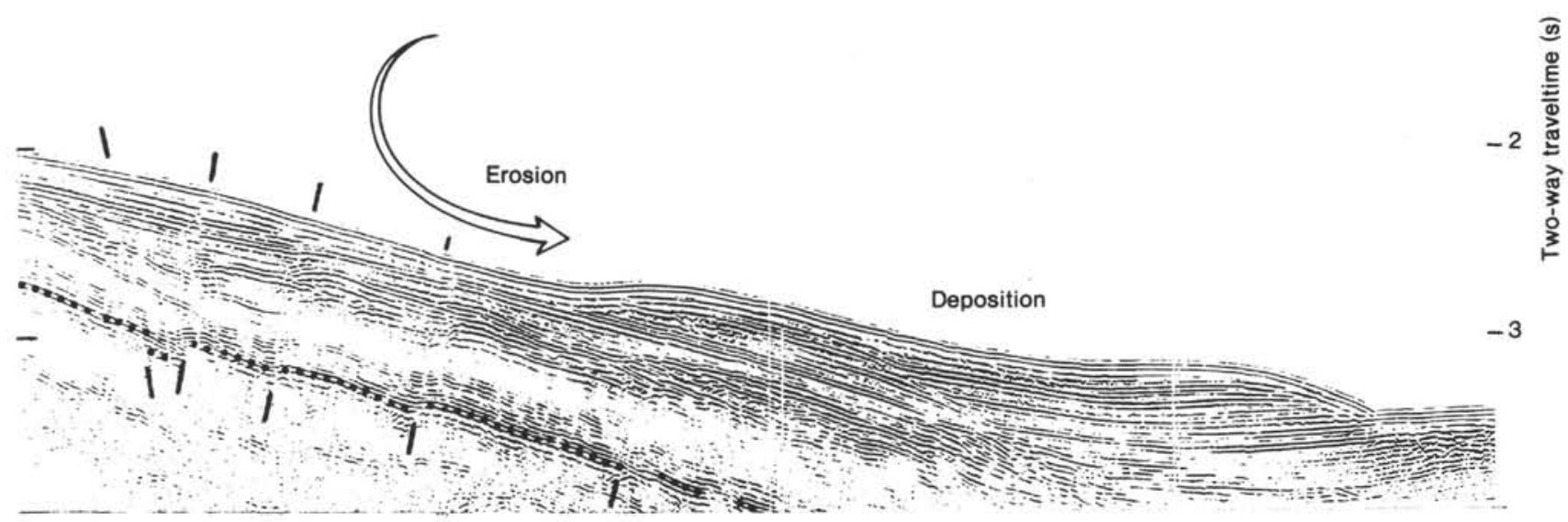

Figure 8. Seismic profile Magellan G-9 across lower North Chatham Slope and adjacent Hikurangi Trough (water depth 1500-2400 m) showing zone of erosion and downslope redeposition. Unconformity Y, at base of acoustic Unit A, is stippled.

the transit profiles. However, on industry profiles an unconformity of about this age can be traced beneath $4 \mathrm{~km}$ of Plio-Pleistocene sediments (Katz, 1974).

In the axis of the Hikurangi Trough the thick sequence of near-horizontal reflectors, which is typical of turbidite basin fill, is cut by a channel several hundred meters deep, which has been partly infilled. This channel meanders along the length of the Hikurangi Trough (Houtz et al., 1961; Lewis, 1980).

The deformation along the steep northwestern margin of the trough (Fig. 5B, 5C) is the southern extremity of a zone of imbricate thrusting associated with subduction of the Pacific Plate and accretion of thick slope- toe sediments to the feather edge of the Indo-Australian Plate (Lewis, 1980; Cole and Lewis, 1981).

\section{DISCUSSION}

\section{Cycles of Erosion and Deposition}

The oldest unconformity on the western Chatham Rise is the surface of the Permian-Jurassic greywackes, planed at the edge of Gondwanaland in the mid-Cretaceous. Initial rifting of New Zealand away from the Australian-Antarctic continent produced tensional half-grabens in the greywacke crust, which filled as the basins developed during the Late Cretaceous (Austin et al., 1973a). 
As acoustic Unit $\mathrm{C}$ was being deposited in early Cenozoic times, the Chatham Rise was already a submarine ridge with sedimentary layers thinning toward its crest. It lay adjacent to low-lying islands being progressively submerged by the sea and supplying only meager amounts of fine detrital material to the adjacent ocean (Fleming, 1962; Stevens, 1980). Deposition throughout the New Zealand Region was slow and overwhelmingly calcareous, with maximum transgression occurring in middle Oligocene times.

Acoustic unconformity $\mathrm{X}$, the strong reflector that locally corresponds with baselap at the base of acoustic Unit B, was not penetrated at Site 594. However, its stratigraphic position and correlations with exploration wells on the adjacent continental margin indicate a mid to late Oligocene age. The obvious correlation is with the regional "Marshall Paraconformity" (Carter and Landis, 1972), which has been alternatively attributed to either erosion by an initially powerful Circum-Antarctic Current which developed as Australia and Antarctica separated (Carter and Norris, 1976), or erosion arising from increased bottom water activity related to climatic cooling in the Oligocene (Kennett, 1977).

Acoustic Unit B represents another cycle of predominantly fine, calcareous deposition lasting from late Oligocene to late Miocene time. Away from the ridge crest, the monotonous succession exhibits only a few low-amplitude reflectors. Coherent reflectors in the lower part of the unit at the edge of the Bounty Trough can be related to lower Miocene distal turbidites in Site 594. Stronger reflectors on the shallower parts of the rise, where Unit B is much thinner, may indicate marginally more current and/or wave activity along the ridge crest.

Unconformity Y, of late Miocene age, indicates an event that caused either erosion or an hiatus in deposition down to considerable water depths. The dating of this event in the drill log appears to correlate closely with the major eustatic fall in sea level recorded at 6.2 Ma (Loutit and Kennett, 1981a, b). This event marked a major glacioeustatic lowering of sea level in the latest Miocene associated with increased Antarctic glaciation (Kennett, 1967).

The crest of the Chatham Rise was planed at this time and exposed Oligocene to mid-Miocene limestones were phosphatized (Cullen, 1980). Much of the phosphatized limestone has remained exposed at the seafloor since then, but the Mernoo Saddle has a thin covering of surficial sediments on the planed Miocene surface.

The highly "stratified" acoustic Unit A represents a totally new regime of sedimentation dominated by large glacio-eustatic oscillations of sea level and increasing input of hemipelagic detrital debris from the rising Southern Alps. Internal convergence within the sequence indicates some low stands of sea level but the sequence as a whole has gradually onlapped the crest of the rise.

\section{Bottom Current Scour or Mass Movement}

There are two alternative explanations for the evident removal of sediment on the northern flank of the rise. The truncated bedding of Unit A could indicate low-an- gled slope failure, possibly triggered by movement of one of the faults (Davey, 1977). The slope in the area of removal is only just over $1^{\circ}$, but slope failure does occur on slopes of $1^{\circ}$ to the north (Lewis, 1973) and to the south (Herzer, 1979) where high rates of sedimentation are considered to have contributed to sediment instability. However, on the northern flank of the Mernoo Saddle, there are no zones of contorted bedding immediately downslope from the truncated bedding; this weighs against, but does not eliminate, the slump hypothesis. An alternative explanation for the truncated bedding is current scour. In favor of this hypothesis is the contourparallel nature of the feature (Fig. 9; also Davey, 1977, fig. 22), which extends at an approximate depth of 700 to $1700 \mathrm{~m}$ deep for at least $50 \mathrm{~km}$ northeast of the Mernoo Saddle. Also, downslope from the sediment removal, acoustic Unit A is relatively thick, with sub-parallel and baselapping reflectors. Together, these observations suggest that contour-following currents, analogous to those in the North Atlantic (Davies and Laughton, 1972) are the principal agents of erosion and deposition. If this is correct, then the current responsible may be some variation of the mid-bathyal flow through the saddle described by Heath (1976), possibly a flow constricted during a period of glacially lowered sea level.

The cause of sediment removal on the southern flank of the rise is equally equivocal. Moatlike features around the South Mernoo Knolls are similar to features produced by bottom current scour in the North Atlantic (Davies and Laughton, 1972). There is also evidence that depressions are part of a large sea-valley system, probably related to mass movement of Unit A (Herzer, 1975).

\section{South Mernoo Volcanics}

Groups of knolls, interpreted as being volcanic in origin, are common on the slope south of the Mernoo Saddle (Herzer, 1975). The evidence of a scour moat at the base of Unit A indicates that there had been enough volcanic activity to have produced some elevation of the seafloor, and resultant turbulent scour, by the late Miocene. No upper age for the features can be demonstrated. No active volcanism occurs in the region today, but volcanism has occurred in southern New Zealand throughout the Cenozoic (Suggate, 1978); the nearest dated volcanism, $200 \mathrm{~km}$ away on Banks Peninsula, is of mainly Miocene age. There is some evidence of a mid-Cenozoic band of alkaline shield volcanoes down the eastern side of New Zealand, and there may be a complementary late Cenozoic band along the edges of the continental crust to the east, perhaps reflecting movement of the Pacific Plate with respect to a linear mantle source (Adams, 1981). Thus, the knolls are most probably mid to late Tertiary in age.

\section{North Mernoo Fault Zone}

The North Mernoo Fault Zone was at first puzzling. Its evident seismic activity and its position, which is limited to the northwest corner of the Chatham Rise (Fig. 9), implies that it is active and related to the very oblique collisional plate boundary at the southern end of the 


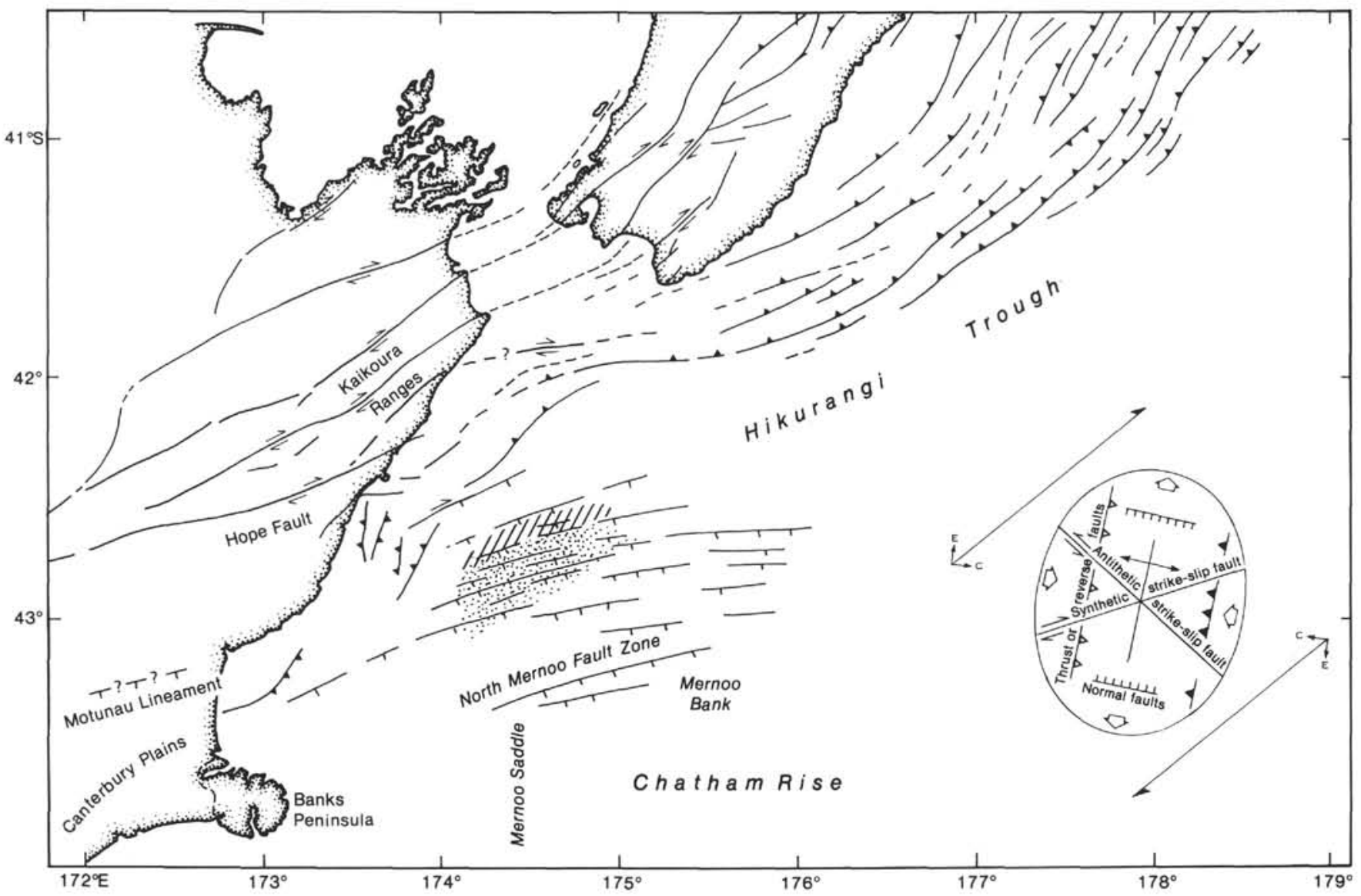

Figure 9. Major faults in vicinity of southern Hikurangi Trough transform plate boundary (from Lewis and Bennett, in press). Tags on faults are down the dip of the fault plane. Triangles are thrust faults and short straight tags are normal faults. Stippling indicates area of erosion and hatching indicates redeposition of top sequence. Inset: structural pattern resulting from a northeast-southwest dextral shear couple (adapted from Reading, 1980).

Hikurangi Trough. But if it is related to a collisional margin, however oblique, why is the faulting apparently tensional?

At many convergent margins, subducting oceanic crust is broken by tensional faults as it is bent and pulled down beneath the overriding plate (Honza, 1980; Schweller et al., 1981; Carey and Dubois, 1981). The faulting pattern is typically one of horsts and grabens, or of normal faults downthrown toward the trench. The northwest corner of the Chatham Rise is not, of course, subducting oceanic crust. However, oceanic crust is being subducted beneath the margin immediately to the north, and the subducted slab has been traced beneath Cook Strait and the northern edge of South Island (Arabasz and Robinson, 1976; Walcott, 1978). It is inferred here that the edge of the continental crust of the Chatham Rise is being pulled down with the contiguous subducting slab of oceanic crust to the north. Certainly the downwarped northwest margin of the Chatham Rise can be traced under thick turbidites in the southern end of the Hikurangi Trough, and the buoyancy of the overridden Chatham Rise may account for the rapid rise of the Kaikoura Ranges.

If this corner of the Chatham Rise is being dragged under the Kaikoura Ranges, why do the normal faults trend east-west? The reason appears to be associated with the fact that the southern Hikurangi segment of the plate boundary is not primarily tensional or compressional but strike-slip (Lewis, 1980). In clay model experiments, strike-slip movement has been shown to produce characteristic structural patterns (Cloos, 1955; Wilcox et al., 1973). A northeast-southwest-trending dextral shear couple (Fig. 9, inset) will produce not only synthetic and antithetic strike-slip faults, but also thrust faults and folds aligned north-northeast-south-southwest, perpendicular to the short, contracting axis of the strain ellipse, and normal faults aligned east-southeastwest-northwest, perpendicular to the expanding axis of the strain ellipse (Reading, 1980). Despite a component of collision at this boundary, a pattern of faults with almost these trends does occur at the southern limit of the Hikurangi Trough (Fig. 9). The north-northeast-southsouthwest thrust faults (and anticlines) are most conspicuous at the western end of the trough and on the adjacent land, where they include west-directed, as well as the more common east-directed, thrusted anticlines (Gregg, 1964; Wilson, 1963). The normal faults are most conspicuous on the flank of the Chatham Rise. Their east-west (rather than east-southeast-west-northwest) 
trend is probably inherited from the strong east-west trend of the Late Cretaceous half-graben system in the underlying basement of the rise.

If the northwest corner of the Chatham Rise is being pulled down while the ridge crest remains buoyant, then why are the faults downthrown toward the crest instead of toward the trough? In fact, in a tensional regime the sense of fault throw matters little. A strain ellipse similar to that for the horizontal components operates in the vertical field, with ordinary synthetic faults downthrown to basin and antithetic faults downthrown updip. Although tensional downbuckling might normally encourage synthetic faulting in an isotropic medium, in this particular case the antithetic system completely dominates. The reason for this is unclear, but the most probable explanation is again that these faults reactivated the Cretaceous structural grain, which is dominated by fault planes with a southerly dip.

\section{CONCLUSIONS}

1. The evolution of the western Chatham Rise is clearly illustrated in seismic profiles obtained in transit to and from Site 594. Basement fault-angle depressions and their infill are the products of a Late Cretaceous period of rifting that immediately preceded the rifting of New Zealand away from Gondwanaland. Overlying sequences, draping both the rise and its flanks, are inferred to be predominantly carbonate sediments that accumulated throughout an early and mid-Tertiary period of wide marine transgression, relative tectonic stability, and sporadic volcanism. Nevertheless, conspicuous hiatuses indicate that deposition was interrupted by major falls in sea level and/or major changes in oceanic circulation. The hiatuses are correlated with major events in the late Oligocene (29 Ma) and late Miocene (6.2 Ma). The top sedimentary sequence, present on the flanks of the rise but absent on the crest, is a stratified layer reflecting increased detrital input from the rapidly rising mountain ranges of New Zealand during late Miocene to late Quaternary periods of glacially lowered sea level.

2 . The causes of erosion and redeposition of the top sequence are equivocal. The most probable explanation appears to be related to the effects of bottom currents, perhaps during glacial periods of lowered sea level, that move parallel to the contours north of the Mernoo Saddle and are disturbed by volcanic knolls south of the saddle.

3. A group of knolls, the South Mernoo Knolls, on the south flank of the rise are volcanic and were at least partly erupted before late Miocene times. They may be related to alkaline volcanics of similar age down the eastern side of New Zealand.

4. An east-west zone of faults, the Mernoo Fault Zone on the northwest edge of the Chatham Rise, consists of antithetic normal faults downthrown toward the rise crest. It is inferred that tensional faults dominate in this area because the edge of the continental crust of the Chatham Rise is being dragged down under the Kaikoura Ranges by the subducting slab to the north. The antithetic system may dominate because it has reactivated the Cretaceous structural grain of the Chatham
Rise basement, which is dominated by east-west normal faults with south-dipping fault planes. The east-west trend, developed along a pre-existing line of weakness, is compatible with the northeast-southwest dextral shear couple at the adjacent transform boundary.

\section{ACKNOWLEDGMENTS}

We are indebted to our colleagues Dr. L. Carter, Dr. D. J. Cullen, Dr. F. J. Davey and Dr. B. W. Davy for their willingness to discuss the data, for their many helpful comments and suggestions, and for their constructive criticism of the manuscript.

\section{REFERENCES}

Adams, C. J., 1981. Migration of late Cenozoic volcanism in the South Island of New Zealand and the Campbell Plateau. Nature, 294: 153-155.

Adams, R. D., and Ware, D. E., 1977. Subcrustal earthquakes beneath New Zealand: locations determined with a laterally inhomogeneous velocity model. N. Z. J. Geol. Geophys., 20:59-83.

Allis, R. G., 1981. Continental underthrusting beneath the Southern Alps of New Zealand. Geology, 9:303-307.

Anon, 1971. Well Résumé Endeavour-I B.P. Shell Todd (Canterbury) Ltd. N. Z. Geol. Surv. Open File Petrol. Rep. 303.

1975. Well Completion Report. Resolution 1. B.P. Shell Todd (Canterbury) Ltd. N. Z. Geol. Surv. Open File Petrol. Rep. 648.

Arabasz, W. J., and Robinson, R., 1976. Microseismicity and geologic structure of northern South Island, New Zealand. N. Z. J. Geol. Geophys., 19:569-609.

Austin, P. M., Sprigg, R. G., and Braithwaite, J. C., 1973a. Structural development of the eastern Chatham Rise and of the New Zealand region. In Fraser, R. (Comp.), Oceanography of the South Pacific, 1972: Wellington (N. Z. Nat. Comm. for UNESCO), pp. 201-215. 1973b. Structure and petroleum potential of eastern Chatham Rise, New Zealand. Bull. Am. Assoc. Pet. Geol., 57:477-97.

Brodie, W. J., and Dawson, E. W., 1971. Antarctic icebergs near New Zealand. N. Z. J. Mar. Freshwat. Res., 5:80-85.

Carey, E., and Dubois, J., 1981. Behaviour of the oceanic lithosphere at subduction zones: plastic yield strength from finite-element method. Tectonophysics, 74:99-110.

Carter, L., 1980. New Zealand Region bathymetry 1:6,000,000 (2nd ed.). N. Z. Oceanogr. Inst. Chart, Misc. Ser., 15.

Carter, L., and Herzer, R. H., 1979. The Hydraulic Regime and its Potential to Transport Sediment on the Canterbury Continental Shelf. N. Z. Oceanogr. Inst. Mem., 83.

Carter, R. M., and Carter, L., 1982. The Motunau Fault and other structures at the southern edge of the Australian/Pacific Plate Boundary, offshore Marlborough, New Zealand. Tectonophysics, $88: 133-159$.

Carter, R. M., and Landis, C. A., 1972. Correlative Oligocene unconformities in southern Australasia. Nature, 237:12-13.

Carter, R. M., and Norris, R. M., 1976. Cainozoic history of southern New Zealand: an accord between geological observations and platetectonic predictions. Earth Planet. Sci. Lett., 31:85-94.

Cloos, E., 1955. Experimental analysis of fracture patterns. Geol. Soc. Am. Bull., 66:241-256.

Cole, J. W., and Lewis, K. B., 1981. Evolution of the Taupo-Hikurangi subduction system. Tectonophysics, 72:1-21.

Cullen, D. J., 1962. The significance of a glacial erratic from the Chatham Rise, east of New Zealand. N. Z. J. Geol. Geophys. 5:309-313. 1965. Autochthonous rocks from the Chatham Rise, east of New Zealand. N. Z. J. Geol. Geophys., 8:465-474.

1967. The age of glauconite from the Chatham Rise, east of New Zealand. N. Z. J. Mar. Freshwat. Res., 1:399-406. 1970. A tectonic analysis of the Southwest Pacific. N. Z. J. Geol. Geophys., 13:7-20.

1980. Distribution, composition and age of submarine phosphorites on Chatham Rise. East of New Zealand. Soc. Econ. Paleont. Mineral., Spec. Publ., 29:139-148.

Davey, F. J., 1977. Marine seismic measurements in the New Zealand region. N. Z. J. Geol. Geophys., 20:719-777.

Davies, T. A., and Laughton, A. S., 1972. Sedimentary processes in the North Atlantic. In Laughton, A. S., Berggren, W. A., et al., 
Init. Repts. DSDP, 12: Washington (U.S. Govt. Printing Office), 905-934.

Ewing, M., Houtz, R., and Ewing, J., 1969. South Pacific sediment distribution. J. Geophys. Res., 74:2477-2493.

Fleming C. A., 1962. New Zealand biogeography: a paleontologists' approach. Tuatara, 10:53-108.

Gregg, D. R., 1964. Hurunui. N. Z. Geol. Surv. Geological Map 1: 250,000. Sheet 18.

Griggs, G. B., Carter, L., Kennett, J. P., and Carter, R. M., 1983. Late Quaternary marine stratigraphy southeast of New Zealand. Geol. Soc. Am. Bull., 94:791-797.

Heath, R. A., 1972. The Southland current. N. Z. J. Mar. Freshwat. Res., 6:497-533.

1976. Oceanic circulation in the head of the Hikurangi Trench, East Coast, New Zealand. N. Z. J. Mar. Freshwat. Res., 10:651-674.

Herzer, R. H., 1975. Uneven submarine topography south of Mernoo Gap-the result of volcanism and submarine sliding (Note). N. Z . J. Geol. Geophys., 18:183-188.

1979. Submarine slides and submarine canyons on the continental slope off Canterbury, New Zealand. N. Z. J. Geol. Geophys., 22:391-406.

1981. Late Quaternary Stratigraphy and Sedimentation of the Canterbury Continental Shelf, New Zealand. N. Z. Oceanogr. Inst. Mem., 89.

Herzer, R. H., and Bradshaw, J. D., in press. The Motunau Fault and other structures at the southern edge of the Australian/Pacific Plate Boundary, offshore Marlborough, New Zealand-Discussion. Tectonophysics.

Honza, E., 1980. Pre-site survey of the Japan Trench transect, Deep Sea Drilling Project. In Scientific Party, et al., Init. Repts. DSDP, 56, 57 (Pt. 1): Washington (U.S. Govt. Printing Office), 449-458.

Houtz, R., Ewing, J., Ewing, M., and Lonardi, A. G., 1967. Seismic reflection profiles of the New Zealand Plateau. J. Geophysics., 72: 4713-4729.

Katz, R., 1974. Margins of the Southwest Pacific.In Burk, C. A., and Drake, C. L. (Eds.), The Geology of Continental Margins: New York (Springer-Verlag), pp. 549-565.

Kennett, J. P., 1967. Recognition and correlation of the Kapitean Stage (Upper Miocene, New Zealand). N. Z. J. Geol. Geophys., 10: 1051-1063.

1977. Cenozoic evolution of Antarctic glaciation and the Circum-Antarctic Ocean and their impact on global paleoceanography. J. Geophys. Res., 82:3843-3859.

Kennett, J. P., and Casey, R. E., 1969. Foraminiferal evidence for a pre-Middle Eocene age of the Chatham Rise, New Zealand. $N$. $Z$. J. Mar. Freshwat. Res., 3:20-28.

Kennett, J. P., Houtz, R. E., Andrews, P. B., Edwards, A. R., Gostin, V. A., Hajós, M., Hampton, M., Jenkins, D. G., Margolis, S. V., Ovenshine, A. T., and Perch-Nielsen, K., 1975. Cenozoic paleoceanography in the Southwest Pacific Ocean, Antarctic glaciation, and the development of the Circum-Antarctic Current. In Kennett, J. P., Houtz, R. E., et al., Init. Repts. DSDP, 29: Washington (U.S. Govt. Printing Office), 1155-1170.

Krause, D. C., and Cullen, D. J., 1970. Bounty bathymetry (2nd ed). N. Z. Oceanogr. Inst. Chart. Oceanic Series, 1:1,000,000.

Lewis, K. B., 1973. Slumping on a continental slope inclined at $1^{\circ}-4^{\circ}$. Sedimentology, 16:97-110.

,1980. Quaternary sedimentation on the Hikurangi obliquesubduction and transform margin, New Zealand. Int. Assoc. Sedimentol., Spec. Publ., 4:171-189.
Lewis, K. B., and Bennett, D. J., in press. Structural patterns on the Hikurangi Margin: an interpretation of seismic data. In Lewis, K. B., (Ed.), New Seismic Profiles, Cores and Detailed Rocks from the Hikurangi Margin. N. Z. Oceanogr. Inst. Field Report.

Loutit, T. S., and Kennett, J. P., 1981a. Australian Cenozoic sedimentary cycles, global sea level changes and the deep sea sedimentary record. Oceanol. Acta., Suppl., pp. 45-63.

, 1981b. New Zealand and Australian Cenozoic sedimentary cycles and global sea-level changes. Am. Assoc. Pet. Geol. Bull., 65:1586-1601.

McDougall, J. C., 1982. Bounty sediments. N. Z. Oceanogr. Inst. Chart. Oceanic Series, 1:1,000,000.

McKenzie, D. P., and Morgan, W. J., 1969. Evolution of triple junctions. Nature, 224:125-133.

Norris, R. M., 1964. Sediments of Chatham Rise. N. Z. Dept. Sci. Industr. Res. Bull. 159 (N. Z. Oceanogr. Instr. Mem. 26).

Pasho, D. W., 1976. Distribution and Morphology of Chatham Rise Phosphorites. N. Z. Oceanogr. Instr. Mem. 77.

Prebble, W. M., 1980. Late Cainozoic sedimentation and tectonics of the East Coast Deformed Belt, in Marlborough, New Zealand. Int. Assoc. Sedimentol., Spec. Publ., 4:217-228.

Reading, H. R., 1980. Characteristics and recognition of strike-ship fault systems. Int. Assoc. Sedimentol., Spec. Publ., 4:7-26.

Ryan, J. M. W., and Scholz, C. H., 1978. Seismotectonics of Arthur's Pass region, South Island, New Zealand. Geol. Soc. Am. Bull., 89:1373-1388.

Schweller, W. J., Kulm, L. D., and Prince, R. A., 1981. Tectonics, structure and sedimentary framework of the Peru-Chile Trench. Geol. Soc. Am. Mem., 154:327-349.

Spörli, K. B., 1980. New Zealand and oblique-slip margins: tectonic development up to and during the Cainozoic. Int. Assoc. Sedimentol., Spec. Publ., 4:147-170.

Stevens, G. R., 1980. New Zealand Adrift: Wellington (Reed).

Stipp, J. J., and McDougall, I., 1968. Geochronology of the Banks Peninsula volcanoes, New Zealand. N. Z. J. Geol. Geophys., 5: 1239-1259.

Suggate, R. P., 1978. The Geology of New Zealand: Wellington (Govt. Printer).

Vail, P. R., and Hardenbol, J., 1979. Sea-level changes during the Tertiary. Oceanus, 22:71-79.

Vail, P. R., Mitchum, R. M., Todd, R. G., Widmier, J. M., Thompson III, S., Sangree, J. B., Bubb, J. N., and Hatelid, W. G., 1977. Seismic stratigraphy and global changes of sea level. In Payton, C. E. (Ed.), Seismic Stratigraphy-Applications to Hydrocarbon Exploration. Am. Assoc. Pet. Geol. Mem. 26:49-212.

Van der Linden, W. J. M., 1968. Cook bathymetry. N. Z. Oceanogr. Inst. Chart. Oceanic Series, 1:1,000,000.

Walcott, R. I., 1978. Present tectonics and late Cenozoic evolution of New Zealand. Geophys. J. R. Astron. Soc., 52:137-164. 1984. Reconstructions of the New Zealand Region for the Neogene. Palaeogeogr., Palaeoclimatol., Palaeoecol., 46:217-231.

Wilcox, R. E., Harding, T. P., and Seely, D. R., 1973. Basic wrench tectonics. Am. Assoc. Pet. Geol. Bull., 57:74-96.

Wilson, D. D., 1963. Geology of Waipara. N. Z. Geol. Surv. Bull., n.s., 64 .

Date of Initial Receipt: 25 June 1984

Date of Acceptance: 4 December 1984 